\title{
A STUDY OF THE CONTENT OF THE LABORATORY COURSE IN HIGH SCHOOL PHYSICS.
}

By E. W. Krebler, Head of the Department of Science, High School, East Lansing, Michigan and Francis D. CurTis, University of Michigan, Ann Arbor, Mich.

\section{Problem.}

The purpose of this investigation is to ascertain (1) the relative frequency with which various laboratory exercises in high school physies appear in widely used laboratory manuals, and (2) the relative importance of these experiments as indicated by judgments of competent experts-teachers of physics in high schools, colleges, normal schools, and universities and teachers of college, normal school and university courses in the teaching of science and in the teaching of physics.

\section{Method.}

All the laboratory exercises found in the following eight laboratory manuals in high school physics were listed with the number of manuals in which each exercise appeared. The eight manuals were:

1. Fuller, Brownlee. Laboratory Exercises. New York. Allyn and Bacon, 1913.

2. Conrad, H. E. Physics Manual and Laboratory Notebook. New York, Mentzer, Bush and Co.

3. Black, N. Henry. Laboratory Manual in Physics. New York, The Maemillan Co., 1923.

4. Good, Frederick. Laboratory Projects in Physics. New York, The Macmillan Co., 1920.

5. Chute, Horatio N. A Laboratory Guide to Accompany Carhart and Chutes Physics. New York, Allyn and Bacon, 1913.

6. Millikan, Robert A.; Gale, Henry Gordon; Bishop, Edwin Sherwood. A First Course in Laboratory Physics for Secondary Schools. New York. Ginn and Company, 1914.

7. Dull, Charles E. Laboratory Exercises in Physics. New York, Henry Holt and Co.

8. Henderson, W. D. Laboratory Exercises in Physics. Chicago, Lyons and Carnahan, 1924.

The complete list of experiments grouped into the five familiar classifications; mechanics, heat, light, sound, electricity and magnetism, but without the numbers indicating their frequency of appearance in the eight manuals, was sent to several hundred experts for evaluation. Through the cordial cooperation of 
professors conducting courses in the teaching of science and in the teaching of physics in the summer sessions of a number of the great universities and teachers colleges, a sampling was secured of individuals representing all parts of the country.

Following an explanation of the nature and purpose of the investigation, these instructions were given for marking the exercises:

Please mark each exercise 1,2 , or 3 , respectively, to indicate whether you consider that exercise to be (1) essential in a one-year high school course in physics, (2) merely desirable if time permits its inclusion, or (3) undesirable in such a course.

At the end of each group, spaces are provided in which you may write the titles of other exercises which are not in the list but which you think should be included in a high school course in physics.

The marker was asked to indicate whether he was a teacher in high school, college, university, or normal school. The failure of many to do this, makes it impossible to indicate the number of judgments contributed by the various groups of teachers.

Judgments were received from ninety-one different individuals.

\section{Findings.}

1. There is considerable diversity of opinion both among the authors of the laboratory manuals and these teachers of physics, regarding what exercises should constitute the laboratory course in high school physies. Of the 175 exercises included in the complete list, none were considered essential to the course by all the evaluators, and only 4 appeared in all 8 laboratory manuals. Table I, however, lists 25 exercises which appeared in more than half the manuals analyzed and which were considered essential by more than half the evaluators. To this list, moreover, may be added the 11 exercises of Table II, all of which appeared in more than half the manuals and only one of which has an average rating value of more than 2.00 ; and also the 20 exercises in Table III, which were considered essential by more than half the evaluators. A rich laboratory course could be selected from the 56 exercises in these three tables. Further choice of selection is offered from the exercises having the highest average rating values in Table IV.

2. Since only two exercises were added by the evaluators to the list secured from the analysis of the laboratory manuals, it seems reasonable to conclude that the combined list of exercises from all the manuals contains the laboratory exercises which are 
appropriate to the subject and which are acceptable to these evaluators.

3. Seventy-three exercises appeared in not more than one of the eight manuals. Tables III and IV indicate, however, that 6 of these were considered essential by more than half the evaluators, and that 35 were considered desirable by more than half the evaluators.

4. Only one exercise, Latent heat of fusion, was evaluated by all 91 evaluators. It is interesting to note in Tables III and IV, that in general those exercises which appeared in few of the manuals were evaluated by relatively few of the evaluators.

Table I. Laboratory Exercises in Physics Appearing in More

Than Half the liaboratory Manuals and Considered Essential by More Than Half the Evaldators. 1

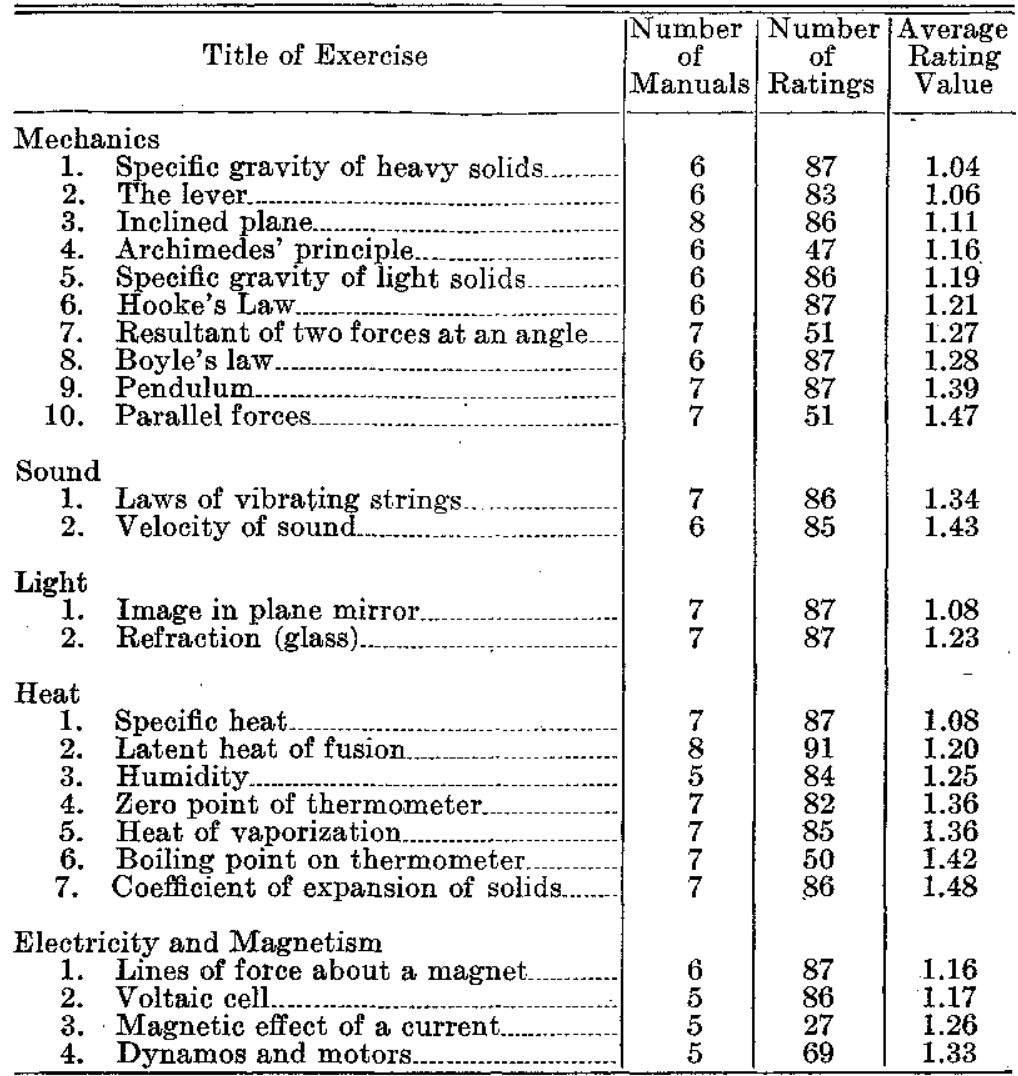

1It would be impossible for an exercise to have an Average Rating Value below 1.50 if fewer than half the evaluators rated it as essential $(1.00)$ 
Table Il. Laboratory Exercises in Physics Appearing in More than half the Manuals but. Considered Essential bx Fewer Than Half the Evaluators.

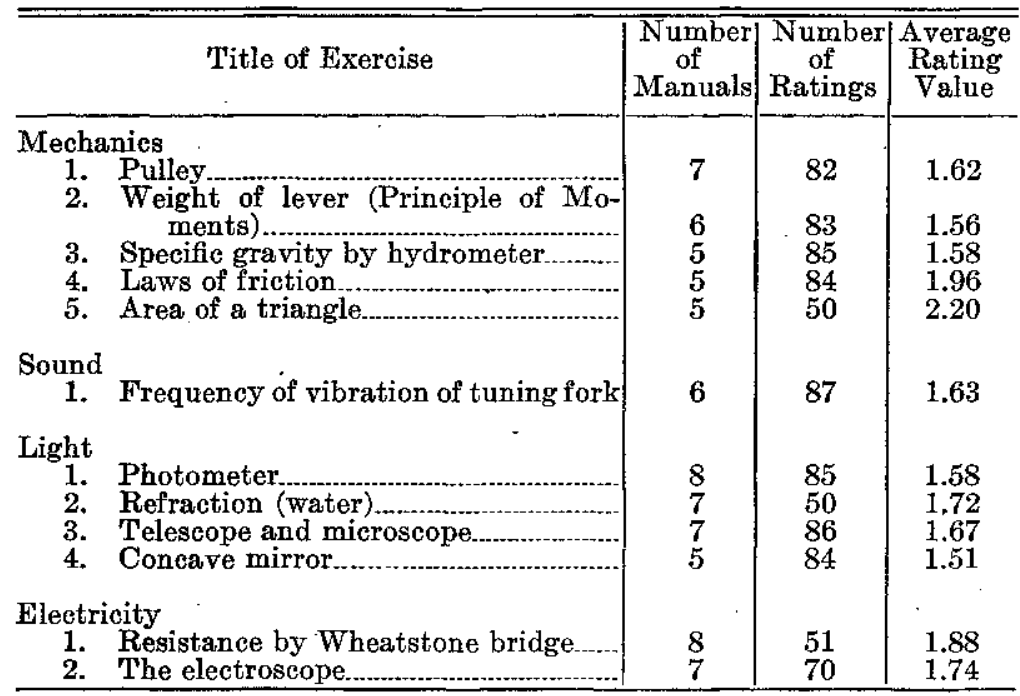

Table III. The Laboratory Exercrses in Physics Appearing in Fewer Than Half the Manuals but Considered Essential by More Than Half the Evaluators.

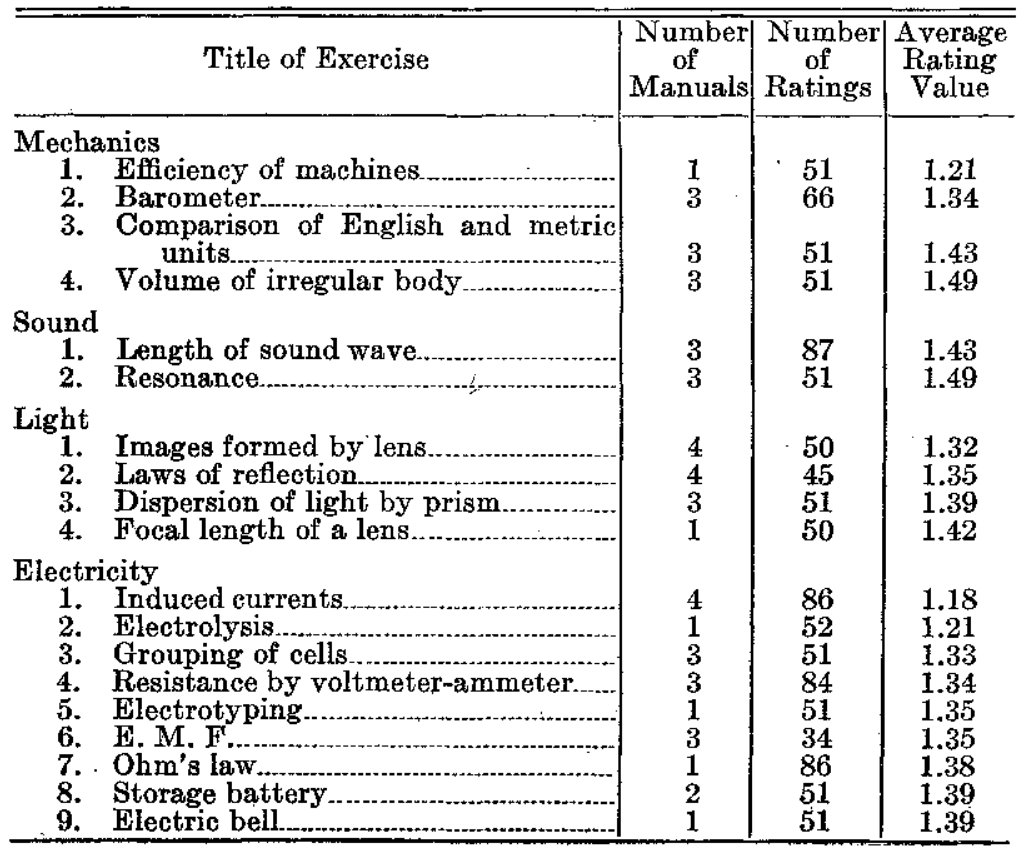


Table IV. Laboratory Exercises Not Included in Tables I and III, which Are Given an Average Rating Value Between "Essential" and "Desirable."

\begin{tabular}{|c|c|c|c|}
\hline Title of Exercise & $\begin{array}{c}\text { Number } \\
\text { of } \\
\text { Manuals }\end{array}$ & $\begin{array}{c}\text { Number } \\
\text { of } \\
\text { Ratings }\end{array}$ & $\begin{array}{l}\text { Average } \\
\text { Rating } \\
\text { Value }\end{array}$ \\
\hline \multicolumn{4}{|l|}{ Mechanics } \\
\hline 1. Wheel and axle. & \multirow{4}{*}{$\begin{array}{l}3 \\
4 \\
3\end{array}$} & \multirow{3}{*}{$\begin{array}{l}50 \\
87 \\
51\end{array}$} & \multirow{4}{*}{$\begin{array}{l}1.54 \\
1.58 \\
1.58\end{array}$} \\
\hline 2. Specific gravity by bottle method. & & & \\
\hline 3. Specific gravity by loss of weight. & & & \\
\hline 4. Specific gravity of liquid by balanc- & & & \\
\hline $\begin{array}{l}\text { mns } \\
\mathrm{a} \text { of gravity }\end{array}$ & $\begin{array}{l}1 \\
1\end{array}$ & 51 & $\begin{array}{l}1.62 \\
1.64\end{array}$ \\
\hline 6. Capillary action.... & \multirow{2}{*}{1} & \multirow{2}{*}{$\begin{array}{l}51 \\
51 \\
51\end{array}$} & \multirow{2}{*}{$\begin{array}{l}1.04 \\
1.70 \\
1.74\end{array}$} \\
\hline 7. Centrifugal force.. & & & \\
\hline 8. Protractor........ & 3 & 82 & \multirow{2}{*}{$\begin{array}{l}1.74 \\
1.74\end{array}$} \\
\hline 9. Use of chemical balances & \multirow{2}{*}{$\begin{array}{l}4 \\
3\end{array}$} & $\begin{array}{l}82 \\
85\end{array}$ & \\
\hline 10. Vernier calipe & & 83 & \multirow{2}{*}{$\begin{array}{l}1.77 \\
1.79\end{array}$} \\
\hline 11. Micrometer caliper. & \multirow{2}{*}{$\begin{array}{l}3 \\
1\end{array}$} & \multirow{2}{*}{$\begin{array}{l}86 \\
51\end{array}$} & \\
\hline 12. Volume of reguls & & & 1.80 \\
\hline 13. Acceleration of $r$ & \multirow{2}{*}{1} & \multirow{2}{*}{$\begin{array}{l}62 \\
50\end{array}$} & \multirow{2}{*}{$\begin{array}{l}1.80 \\
1.80 \\
1.84\end{array}$} \\
\hline 14. Forces acting upon & & & \\
\hline 15. Weight of $1 \mathrm{cc}$ of & & 51 & \multirow{5}{*}{$\begin{array}{l}1.88 \\
1.92 \\
1.92 \\
1.92 \\
1.93\end{array}$} \\
\hline 16. The linear scale... & \multirow{3}{*}{$\begin{array}{l}1 \\
1 \\
2\end{array}$} & \multirow{2}{*}{$\begin{array}{l}50 \\
50\end{array}$} & \\
\hline 17. Force at & & & \\
\hline 18. Lift pum & & 51 & \\
\hline 19. Law of float & 2 & 49 & \\
\hline 20. Weight by s & \multirow{3}{*}{$\begin{array}{l}2 \\
3\end{array}$} & & \\
\hline & & 49 & 1.95 \\
\hline 21. Relation of de & & 51 & 1.96 \\
\hline 22. Weig & 2 & 51 & 1.98 \\
\hline 23. Density of air & 3 & 51 & 1.98 \\
\hline ound & & & \\
\hline 1. Interference of sound waves. & 1 & 50 & 1.80 \\
\hline Light & & & \\
\hline 1. Color.. & 1 & 51 & 1.66 \\
\hline 2. Spectra & 1 & 49 & 1.69 \\
\hline 3. Illuminating and lighting. & $\overline{1}$ & 51 & 1.74 \\
\hline 4. Optical c & 1 & 50 & 1.90 \\
\hline 5. Cónjugate foc & $\mathbf{1}$ & 50 & 1.92 \\
\hline 6. Total reflection. & 2 & 51 & 1.96 \\
\hline Heat & & & \\
\hline 1. Coefficient of $\mathrm{e}$ & 4 & 51 & 1.70 \\
\hline 2. Boiling & 3 & 49 & 1.73 \\
\hline 3. Effect of solution upon temperature & 2 & 51 & 1.76 \\
\hline 4. Stes & 1 & 51 & 1.78 \\
\hline 5. Conduction of heat & 1 & 51 & 1.78 \\
\hline 6. Gasc & 1 & 51 & 1.78 \\
\hline 7. Mec & 1 & 67 & 1.80 \\
\hline 8. Law & 2 & 65 & 1.84 \\
\hline 9. Effect of solids in solution upon boil- & & & \\
\hline 10. Increase in volume at constant pres- & 2 & 51 & 1.90 \\
\hline 2. & 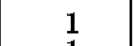 & 51 & 1.94 \\
\hline on density of wate & 1 & 51 & $1: 94$ \\
\hline of gas at co & 3 & 51 & \\
\hline
\end{tabular}


13. Heat changes through solution and

14. Boiling phenomena

Electricity

1. Heating effect of a current

2. The telephone

3. Rheostats and resistance.

4. Electric light and power

5. Alternating current

6. Electroplating.

7. Polarity of a magnet

8. Resistance of conductors in series and parallel.

9. Telegraph instruments

10. First law of magnetism

11. Fall of potential along a conductor

12. The shunt.

13. Efficiency of electric motor..

14. Study of incandescent lamps

15. Internal resistance of a cell

16. Polarization and recovery.

17. Molecular nature of magnetism.

18. Static electric effects

19. Wireless

20. Magnetic strength

21. Effect of temperature on resistance...

22. Magnetic substances.

FROM THE SCRAPBOOK OF A TEACHER OF SCIENCE.

By DUane Roller, The University of Oklahoma, Norman, Okla.

In defense of accuracy we must be zealous, as it were, even to slaying.-P. G. Tait.

Extinguished theologians lie about the cradle of every science, as the strangled snakes besides that of Hercules.-Thomas Henry Huxley.

... behind all your practical applications, there is a region of intellectual action to which practical men have rarely contributed, but from which they draw all their supplies. Cut them off from this region, and they become eventually helpless.-John Tyndall in "Lectures on Light."

Why is an object seen .erect when its image on the retina is inverted? In answer to this question the equally sensible question is sometimes asked: when one hears a baby cry with two ears, why does one not take it for twins?-Wm. S. Franklin and Barry MacNutt in "A Calendar of Leading Experiments."

Say first, of God above or man below,

What can we reason but from what we know? -Alexander Pope, "Essay on Man."

"Sperrit? Well, maybe," he said. "But there's one thing not clear to me. There was an echo. Now, no man ever seen a sperrit with a shadow; well, then, what's he doing with an echo to him, I should like to know? That ain't in natur', surely?" Long John Silver, in Stevenson's "Treasure Island," attempting to quiet the fears of his superstitious accomplices, who think they hear the ghost of the terrible Captain Flint. 